\title{
Eligibility Criteria for Legal Aid: Comparative Analysis
}

\author{
Anželika Banevičienè \\ State-Guaranteed Legal Aid Service, Vilnius, Lithuania
}

\begin{abstract}
The free movement of people guaranteed in the EU encourages people to move their place of residence from one Member State to another. It is essential to ensure equal protection of their rights in all EU countries. Protection of the right to access to justice cannot be ensured without an effective legal aid provision to economically disadvantaged and vulnerable groups of people. EU countries are all very different, and so too is the regulation of their national systems of legal aid. The article provides an overview of 14 EU countries-Lithuania, Germany, Netherland, Spain, France, Belgium, Italy, Denmark, Poland, Sweden, Finland, Hungary, Ireland, and UK (England \& Wales, Scotland, and Northern Ireland), identifying similarities and differences in the assessment of person's eligibility for the legal aid in civil cases.
\end{abstract}

Keywords: free legal aid, state-funded legal aid, eligibility criteria, means and merit test, first-line legal aid, second-line legal aid

\section{Introduction}

EU countries are all very different, and so too is the regulation of their national systems of legal aid. Some countries allow independent institutional bodies to make decisions on legal aid provision ${ }^{1}$ whereas others give this role to courts ${ }^{2}$ or bar associations ${ }^{3}$. In addition to the differences in the institutional frameworks, there are even bigger differences between the scope of legal aid and eligibility criteria for legal aid.

Despite the fact that, based on the requirements of the EU regulation in each EU country, legal aid is available to those who are citizens of the country or of another EU Member State, and to other natural persons residing lawfully in the particular country and other EU Member States as well as to persons whose rights have to be defended based on international, regional, or bilateral treaties, the amount of legal aid and accessibility for legal aid differ among the countries.

Countries have different approaches but they all have the same aim - to assure vulnerable citizens or those with lower incomes equal possibilities to receive quality legal aid and defend their rights in court.

The free movement of people guaranteed in the EU encourages people to move their place of residence from one country to another. It is essential that they know about available instruments for defending their rights. One of these is the availability of state-funded legal aid. However, not all have access to it. It is possible that someone eligible for legal aid in one country is not eligible in another.

Anželika Banevičienė, Doctor of Laws, the international expert on legal aid and human rights; the director of the State-Guaranteed Legal Aid Service, Vilnius, Lithuania.

1 E.g. Lithuania, England \& Wales, Scotland, Northern Ireland, Ireland, Netherland, Finland, Sweden (first-line legal aid), Hungary (first-line legal aid).

2 E.g. Germany, France, Italy, Sweden (second-line legal aid), Hungary (second-line legal aid).

${ }^{3}$ E.g. Spain, Belgium. 
The article provides an overview of 14 EU countries - Lithuania, Germany, Netherland, Spain, France, Belgium, Italy, Denmark, Poland, Sweden, Finland, Hungary, Ireland, and UK (England \& Wales, Scotland, and Northern Ireland), identifying similarities and differences in the assessment of person's eligibility for the legal aid in civil cases. The analysis is performed taking into account variations in the scope of legal aid.

Legal aid can be divided into two main groups: first-line legal aid, i.e., pre-litigation consultancy service and second-line legal aid: representation and defence in all type of proceedings. In each country, both of them are regulated in different ways. There are differences in who is eligible, based on that the analysis is performed considering the line of legal aid provision.

\section{First-Line Legal Aid: Pre-litigation Consultancy Service}

In order to guide people on whether their rights are infringed, how to defend them, and what are the possibilities for defending them, a pre-litigation consultancy service has been established in most EU countries, except Italy. This type of legal aid is mainly dedicated to natural persons. In a few countries, corporate bodies, such as public-interest associations and foundations (non-profit) can avail of this service. ${ }^{4}$

Some countries define the list of people to whom pre-litigation consultancy service can be provided. For example, such practice existed in Poland. ${ }^{5}$ Before legal regulation was changed in 2019, Art. 4.1 of The Act on Free Legal Assistance and Legal Education defined that assistance can be provided to: natural persons who have been awarded a welfare benefit in the 12 months preceding the application; large family card holders, war veterans, victims of war repression and the post-war period, young people up to the age of 26 , senior citizens aged $65+$ and those who, as a result of a natural disaster, or technical emergency, were in a hazardous situation or suffered damages. ${ }^{6}$

The name of the service is different (primary legal aid, ${ }^{7}$ first-line legal aid, ${ }^{8}$ legal advice, ${ }^{9}$ legal assistance $^{10}$, advisory assistance ${ }^{11}$, legal advice and assistance, ${ }^{12}$ and legal assistance and legal education ${ }^{13}$ ) but the meaning is similar. However, the scope of this pre-litigation consultancy service differs between EU countries.

All the countries studied, who have established a pre-litigation consultancy service, agree that at a minimum it should include provision of legal information and legal advice. This type of legal aid includes provision of information on the legal status quo, rights one is entitled to, and obligations imposed; presentation of the manner in which the legal problem can be solved, etc. This makes it possible for people to make an

\footnotetext{
${ }^{4}$ Belgium, The Judicial Code of 1967, Belgium, JUSTEL (2018), Art. 508/1(1); Spain, Law 1/1996 on Free Legal Aid, Spain, Pub.L.No. BOE-A-1996-750, Agencia Estatal Boletin Oficial del Estado (2018), Art. 2(c)(1)(2).

${ }^{5}$ Law on Free Legal Assistance and Legal Education of 2015, Poland, Dz.U. 2015 poz. 1255, ISAP (2015), Art. 4(1).

${ }^{6}$ The Law was changed in 2019 defining that everyone who is unable to pay the costs of legal assistance can get free legal assistance and consultations (Law on Free Legal Assistance and Legal Education of 2015, Poland, Dz.U. 2015 poz. 1255, ISAP (2019), Art. 4(1)).

${ }^{7}$ Lithuania, The Law VIII-1591 on State-Guaranteed Legal Aid, Lithuania, Official Gazette, 12 April 2000, No. 30-827, i. k. 1001010ISTAIII-1591, (2019) Art. 2(6).

8 Belgium, Judicial Code of 1967, Art. 508/1(1).

9 England \& Wales, Legal Aid, Sentencing and Punishment of Offenders Act 2012 (c. 10) of England \& Wales, The National Archives (2012), Art. 8(1); Ireland, Civil Legal Aid Act, 1995, Ireland, Pub.L.No. 32 of 1995, eISB (2019), Art. 25.

102003 LXXX. Law on Legal Aid, Hungary, Wolters Kluwer Hungary Kft. (2017), §1(1).

${ }^{11}$ Germany, Advisory Assistance Act of 18 June 1980 (BGBl. I p. 689), which was last amended by Article 140 of the Ordinance of 31 August 2015 (BGB1. I p. 1474), Germany, juris Das Rechtsportal (2015), §2(1).

12 Scotland, Legal Aid (Scotland) Act 1986, Pub.L.1986 c. 47, The National Archives (2018), Art. 6(1).

13 Poland, Law on Free Legal Assistance and Legal Education, Art. 1.
} 
informed legal decision.

Defining the scope of a pre-litigation consultancy service, the law is constructed in different countries in different ways. One group of countries defines that this type of legal aid is provided in all legal matters of all fields of law with some exemptions, whereas another group of countries directly specifies the legal matters in which legal aid is provided.

In particular, the legal advice in all type of legal matters related to domestic law is provided in Germany, ${ }^{14}$ Lithuania $^{15}$, Sweden ${ }^{16}$, and Scotland. ${ }^{17}$ In addition, there are some exemptions. For example, in Denmark, ${ }^{18}$ detailed consultations are not available in cases concerning the circumstances of active business owners; in Poland, ${ }^{19}$ legal assistance does not cover matters related to running business activity, except preparation for starting a business.

Regarding the group of countries which directly specify the fields of law in which pre-litigation advice is provided, England and Wales ${ }^{20}$ can be cited as examples. In this country, legal aid is provided in areas, such as: debt, if a home is at risk; housing, if homeless or at risk of being evicted; domestic abuse; separating from an abusive partner, when making arrangements for children or sorting out money and property; a child being taken into care; special education needs; discrimination; some child abduction cases; and advice for a person accused of a crime when in police custody.

In addition to the provision of legal information and legal advice, the scope of pre-litigation consultancy is wider in some countries. Some countries provide practical advice on a variety of issues, ${ }^{21} \mathrm{draft}$ documents to be submitted to state and municipal institutions, ${ }^{22}$ prepare a draft of a request to the court for exemption from court fees or appointment of a lawyer or legal adviser in court proceedings, or draft a pleading to the extent necessary to provide legal assistance out of $\operatorname{court}^{23}$ and legal assistance for defending the interests of the legal aid beneficiary against another person (writing, for example, a letter to that person containing the facts of the case or indicating the legal position). ${ }^{24}$

In addition, there are countries which provide information and guidance on alternative dispute resolution systems (mediation) ${ }^{25}$ or even offer mediation ${ }^{26}$ or advice on an out-of-court settlement of a dispute and actions for the amicable settlement of a dispute or drafting of a settlement agreement. ${ }^{27}$

Some countries have established a mandatory "Telephone Gateway" for particular types of cases. For example, in England and Wales, advice on debt, discrimination, and consultation on special educational needs is only accessible via the Civil Legal Advice telephone helpline. There are exemptions for children under 18 years old, those in detention and emergency cases.

${ }_{15}$ Advisory Assistance Act of 18 June 1980, §2(2).

15 The Law VIII-1591 on State-Guaranteed Legal Aid, Art. 2.

16 The Legal Aid Act (1996: 1619), Sweden, SFS No. 1996: 1619, Sveriges Riksdag (2016), §2.

17 Scotland, Legal Aid (Scotland) Act 1986, Art. 6(1).

18 Danish Administration of Justice Act of 1996, Pub.L.No. LBK No. 1139, Ministry of Justice (2013), §323(4)(2).

19 Law on Free Legal Assistance and Legal Education, Art. 3(2).

${ }^{20}$ Legal Aid, Sentencing and Punishment of Offenders Act 2012, Schedule 1.

${ }^{21}$ Belgium, Judicial Code of 1967, Art. 508/1(1).

22 Lithuania, The Law VIII-1591 on State-Guaranteed Legal Aid, Art. 2(6).

${ }^{23}$ Poland, Law on Free Legal Assistance and Legal Education, Art. 3(1)(4).

${ }_{24}$ Germany, Advisory Assistance Act of 18 June 1980, §2(1).

25 Spain, Law 1/1996 on Free Legal Aid, Art. 6(1).

26 Poland, Law on Free Legal Assistance and Legal Education, Art. 3(1)(3a).

27 Lithuania, The Law VIII-1591 on State-Guaranteed Legal Aid, Art. 2(6). 
In sensitive fields, pre-litigation consultancy service is provided in cooperation with non-governmental associations. For example, in France, associations for victims, consumers associations, etc. are largely involved when legal aid provision is related with gender violence, infringement of rights of consumers, and so on.

Finally, there are countries which do not provide a pre-litigation consultancy service completely (Italy).

Differences between the countries exist not only in the scope of the pre-litigation consultancy service but also the duration of the service and a requirement to pay for it, coverage of costs.

Some countries provide this type of legal aid service free of charge irrespective of the person's financial situation; ${ }^{28}$ however, some of them limit the duration of the aid. For example, in Lithuania, a one-hour consultation is free of charge. Only in exceptional cases can the duration be extended.

In other countries, such as Germany, Belgium, and Ireland, there are no limits on the duration of this pre-litigation consultancy service; however, in some countries, the service is not free of charge ${ }^{29}$. For example, in Germany, there is a fixed fee of EUR 15. In addition, it should be mentioned that not everyone can avail of this type of legal aid. Pre-litigation consultancy service is provided only for those who do not have the necessary means because of their personal and economic circumstances. ${ }^{30}$

In Ireland, ${ }^{31}$ Northern Ireland, ${ }^{32}$ and England \& Wales, ${ }^{33}$ the contribution amount depends on the requestor's disposable income and assets. In Ireland, the minimum advice contribution is EUR 30. Depending on the requestor's income, he/she might have to pay up to EUR 150. Only in exceptional circumstances is payment of the contribution waived. ${ }^{34}$ In all countries, assessment of the financial situation is similar to that used in the assessment for legal aid provision in court proceedings.

The third version is in Denmark and Belgium. In Denmark, ${ }^{35}$ basic oral/verbal advice on any legal question is provided free of charge, however, advice beyond basic oral advice including correspondence with the other party in the dispute or seeking a settlement is provided for a fee. The fee is reduced if the financial situation of the legal aid beneficiary is below a defined financial threshold. In Belgium, coverage of practical advice on a variety of issues is free of charge, however, costs for more detailed legal opinions, establishing the necessary contacts, drafting letters, accompanying the client to meetings with government institutions and even in situations leading up to actual proceedings depend on the financial situation of the legal aid beneficiary ${ }^{36}$.

It should also be mentioned that some countries, for example, Sweden, ${ }^{37}$ do not provide detailed pre-litigation consultancy service for those who have litigation insurance.

In addition to that, it should be pointed out that some countries require the legal aid beneficiary to consent to pay the full costs for the pre-litigation consultancy service provided if the case is successful. ${ }^{38}$ For example, in Germany, the legal aid provider can demand higher amounts in cases where the legal assistance was so successful that the financial situation of the beneficiary has been improved significantly (for example, the claim or

${ }^{28}$ Lithuania, The Law VIII-1591 on State-Guaranteed Legal Aid, Art. 14(4); Poland, Law on Free Legal Assistance and Legal Education, Art. 1.

${ }^{29}$ Except, in Belgium lawyers cannot clime fees for the first-line legal aid provision, Judicial Code of 1967, Art. 508/5(2).

${ }^{30}$ Germany, Advisory Assistance Act of 18 June 1980, §1.

31 Civil Legal Aid Act, 1995, Art. 29(1).

${ }_{32}$ Legal Aid, Advice and Assistance (Northern Ireland) Order 1981, Pub.L.No. 228 (N.I. 8), The National Archives (2012), Art. 7.

33 Legal Aid, Sentencing and Punishment of Offenders Act 2012, Art. 23.

34 Civil Legal Aid Act, 1995, Art. 29(2).

35 Danish Administration of Justice Act, §323(3).

${ }^{36}$ More detailed legal opinions belongs to the secondary legal aid, The Judicial Code of 1967, Belgium, Art. 508/1(2).

${ }^{37}$ Legal Aid Act (1996: 1619), §9.

38 Scotland, Germany. 
compensation was paid, an inheritance was disbursed). They have the right to get the pre-agreed fee, additionally. The legal aid provider must notify the beneficiary about this condition in advance. However, it should also be mentioned that there is no charge for legal assistance in Germany if the costs are reimbursed by third parties.

It should also be pointed out that if a person brings a wrongful demand against another party, who asks for legal assistance, the person has to cover the expenses incurred by that party.

Finally, it should be mentioned that some countries apply a merit test as eligibility criteria for pre-litigation consultancy service provision. For example, in Germany, the legal advice is provided if the request for legal advice does not appear to be wanton. ${ }^{39}$ Whereas in Lithuania, ${ }^{40}$ despite the fact that a means test is not applicable to primary legal aid provision, the requirements foreseen in the merit test have to be fulfilled. The law on state-guaranteed legal aid defines that primary legal aid is not provided, when claims are manifestly unfounded; legal aid has already been provided on the same issue; it is obvious that it is possible to obtain a lawyer's advice without resorting to state-guaranteed legal aid; the applicant requested legal aid for an issue which is not related to his own rights and legitimate interests; the applicant misuses his rights on legal aid, material or procedural rights.

\section{Second-Line Legal Aid}

Second-line legal aid is legal aid provided in court proceedings. Similar to the first-line legal aid, this type of legal aid is mainly dedicated to natural persons. Regarding legal entities, it should be mentioned that, comparing to the first-line aid, more states provide second-line legal aid to public-interest associations and foundations (non-profit). ${ }^{41}$ In addition, in some countries, for example, Sweden ${ }^{42}$, in exceptional cases a business proprietor can be granted legal aid.

Not all countries provide second-line legal aid in all fields of law. Some countries provide legal aid only in civil and administrative cases, ${ }^{43}$ civil and criminal cases ${ }^{44}$ whereas others provide legal aid in all fields of law. ${ }^{45}$ There are countries which refer to representation in civil and administrative proceedings only and representation of victims of sexual assault in criminal proceedings as "legal aid", whereas legal aid to suspect, accused or sentenced persons is referred to differently - nomination of a public defender or legal counsel (Sweden).

Some countries restrict the provision of legal aid defining the field in which legal aid is or is not provided. For example, in England \& Wales, ${ }^{46}$ the main categories covered are: public family law, i.e., care proceedings; private family law where there has been domestic violence/abuse; family mediation; housing relating to serious damages, homelessness or repossession; asylum and the residual immigration matters referred to above; mental

\footnotetext{
39 Advisory Assistance Act of 18 June 1980, §1(1)(1).

40 The Law VIII-1591 on State-Guaranteed Legal Aid, Art. 11(6).

${ }^{41}$ Spain, Law 1/1996 on Free Legal Aid, Art. 2(c); Italy, The Ministry of Justice of the Italy, Practical Sheet-Patronage at the Expense of the State in Civil and Administrative Proceedings, (2019), https://www.giustizia.it/giustizia/en/mg_3_7_2.page;jsessionid=Z3YeqzJRc0YblyI7hawlnwkI?tab=d; Poland, Act of 17 November 1964, The Code of Civil Procedure, Poland, Dz.U. 1964 nr 43 poz. 296, ISAP (2019), Art. 117(3); France, Law No. 91-647 of 10 July 1991 on Legal Aid, France, NOR: JUSX9100049L, Legifrance (2019), Art. 2; Netherland, Legal Aid Act of 1993, Pub.L.No. BWBR0006368, Wettenbank (2019), Art. 12(1).

42 Sweden, Legal Aid Act (1996: 1619), §13.

43 Denmark.

${ }^{44}$ Poland.

45 Spain, Lithuania, France, Belgium.

${ }^{46}$ Legal Aid, Sentencing and Punishment of Offenders Act 2012, Schedule 1.
} 
health; community care; statutory discrimination; special educational needs; and public law, for instance judicial review. Whereas the following categories of law-related cases are not covered by legal aid: private family law, except where there has been domestic violence and for child abduction cases; employment law unless it concerns a statutory discrimination issue or a claim by a victim of human trafficking; housing law that does not relate to serious disrepair, homelessness, or possession proceedings; welfare benefits, except for higher appeals to the second-tier tribunal, or higher courts; debt, except where there is an immediate risk of home repossession; non-asylum immigration cases, except for immigration bail applications, applications under the domestic violence immigration rule and, for victims of human trafficking; education cases, except for special educational needs cases; clinical negligence cases, except for babies up to eight-weeks old. Citizens may be able to get legal aid in other exceptional cases, if they can prove that being refused legal aid would infringe their rights under the European Convention on Human Rights (ECHR) and EU rights to legal representation.

In most countries, second-line legal aid provision is restricted to the home country. However, in some countries, legal aid is provided abroad in exceptional situations. For example, in Sweden ${ }^{47}$, a victim of sexual violence, i.e., "she has been raped or has been sexually molested on holidays", can get legal aid. In such situation, the government pays part of the cost of the legal counsel (attorney or lawyer) and any travel expenses incurred in attending the trial in the other country.

The scope of second-line legal aid includes two main groups.

First group: appointment or selection of lawyer, procedural representative, or mediator:

- appointment or selection of a lawyer, who drafts procedural documents and represents in court in all levels of the proceedings (including the process of enforcement) $;^{48}$

- appointment of a procedural representative in court (state procurator ${ }^{49}$ );

- appointment of a mediator; ${ }^{50}$

Second group: coverage of costs of proceedings:

- coverage of litigation costs including lawyers' fees ${ }^{51}$ (in case, they would have been covered by a client without legal aid support);

- exemption from court fees or its coverage, $;^{52}$

- coverage of costs of mediation, ${ }^{53}$

- coverage of the expenses of a bailiff to start the execution of a court decision. ${ }^{54}$

All countries studied cover the fees of a lawyer. In some countries, the fees of lawyers for legal aid provision are fixed and basically, they are lower than fees in the market. ${ }^{55}$ Whereas in others, for example, Sweden,

\footnotetext{
${ }^{47}$ Legal Aid Act (1996: 1619), §21, 22.

48 Lithuania, The Law VIII-1591 on State-Guaranteed Legal Aid, Art. 2(1); Spain, Law 1/1996 on Free Legal Aid, Art. 6(3); France, Law No. 91-647 on Legal Aid, Art. 19, Poland, The Code of Civil Procedure 117(1)(2).

49 Spain, Law 1/1996 on Free Legal Aid, Art. 6(3).

${ }^{50}$ Lithuania, The Law VIII-1591 on State-Guaranteed Legal Aid, Art. 2(12).

51 Lithuania, Law VIII-1591 on State-Guaranteed Legal Aid, Art. 14(2); Italy, Tribunale di Urbino, Brief Guide to Legal Aid, §1 (2019), http://www.tribunaleurbino.it/it/Content/Index/13581; Finland, Legal Aid Act, §4(1)(1); Sweden, Legal Aid Act (1996: 1619), §§15-18.

${ }_{52}$ Lithuania, Law VIII-1591 on State-Guaranteed Legal Aid, Art. 2(1); Sweden, Legal Aid Act (1996: 1619), §19.

53 Lithuania, Law VIII-1591 on State-Guaranteed Legal Aid, Art. 14(3); Sweden, Legal Aid Act (1996: 1619), §18.

${ }_{55}^{54}$ Lithuania, Law VIII-1591 on State-Guaranteed Legal Aid, Art. 2(1); Sweden, Legal Aid Act (1996: 1619), §19.

55 Lithuania Resolution of the Government of the Republic of Lithuania (No. 364), "On the Approval of the Rules on the Charge Rates Paid for the Provision of Secondary Legal Aid, Coordination and Mediation and the Payment Thereof" of 13 April 2016 , TAR, 2016-04-15, Nr. 9599, i. k. 2016-09599; Germany, The Law on the Remuneration of Lawyers of 5 May 2004 (BGBl. I p. 718, 788), which was last amended by Article 8 of the law of 17 December 2018 (BGB1. I p. 2573).
} 
coverage of legal aid is the difference between the reasonable costs that arise for someone's legal representation and the legal aid fee which the legal aid beneficiary has to pay himself. The legal aid fee is a percentage of the total cost of the legal aid provider. If the financial circumstances of the legal aid beneficiary change significantly during the proceedings, the fee changes as well. ${ }^{56}$

Some countries cover a defined percentage of all costs related to the proceeding, ${ }^{57}$ whereas in others, there are limits to the types of expenses that are covered and how much is covered. For example, in Sweden, being granted legal aid does not automatically mean that the state pays all the costs for legal representation. The basic idea is that everyone should contribute to the cost to the extent they can afford. Accordingly, everyone can receive up to 100 hours of legal aid for the whole or part of the cost of a legal representative. Only in exceptional situations can the duration of legal aid be extended. In addition, the costs that are covered are defined: i.e., reasonable costs for submitting evidence in a general court, the Labour Court and the Commercial Court; costs of an investigation which is reasonably required to safeguard your rights, up to a maximum of SEK 10,000; and court fees. ${ }^{58}$ Any expenditure that is not covered by legal aid is therefore the responsibility of the legal aid beneficiary.

Regulation on this issue is similar in Finland. In Finland, ${ }^{59}$ legal aid covers the measures of the attorney for at most 80 hours. It also covers the costs of those measures of a lawyer that are necessary in view of the nature and extent of the matter, the value of the object of the dispute and the circumstances as a whole; the fees and reimbursements arising from the interpretation and translation services required in the consideration of the matter; handling charges, document charges, and the reimbursement of miscellaneous expenses in the authority seized of the main matter; the compensation for witnesses called by a party receiving legal aid; the other costs of evidence submitted by a party receiving legal aid necessary for the resolution of the matter. Legal aid may be limited to predetermined measures only.

In some countries, there is a requirement to pay a contribution ${ }^{60}$ in order to get civil and administrative legal aid which depends on the disposable income and assets of the legal aid beneficiaries. However, in some countries, there is a defined minimum legal aid contribution. For example, in Ireland ${ }^{61}$ the minimum legal aid contribution is EUR 130; in asylum or subsidiary protection cases, the contribution is EUR 10. Contributions can be paid in instalments but must be paid within 12 months. Only in cases where paying the contribution would cause legal aid beneficiary undue hardship can it be waived.

In general, the party that loses the process has to pay the costs of the opposite party, even if legal representation (representation of lawyer) was granted. There are only a few countries which cover the costs awarded to the other party in the proceedings in a situation where the party in possession of free legal aid loses the case. ${ }^{62}$

\footnotetext{
56 Sweden, Legal Aid Act (1996: 1619), §§23, 27-29.

57 Lithuania, The Law VIII-1591 on State-Guaranteed Legal Aid, Art. 14(5) and others.

58 Sweden, Legal Aid Act (1996: 1619), §15-19.

59 Finland, Legal Aid Act, Pub.L.No. 257/2002, FINLEX (2016), §5.

60 England \& Wales, Legal Aid, Sentencing and Punishment of Offenders Act 2012, Art. 23; Germany, Germany, The Code of Civil Procedure as amended on 5 December 2005 (Federal Law Gazette I p. 3202; 2006 I p. 431; 2007 I p. 1781), last amended by Article 1 of the Law of 31 January 2019 (Federal Law Gazette I p. 54), §114; Lithuania, Law VIII-1591 on State-Guaranteed Legal Aid, Art. 11(7) and 19.

${ }^{61}$ The Legal Aid Board of Ireland, Paying for Your Civil Legal Aid and Advice, https://www.legalaidboard.ie/en/our-services/legal-aid-services/how-much-will-i-have-to-pay-/.

62 Denmark, Danish Administration of Justice Act, $\$ 331(4)$.
} 
In addition, it should be mentioned that in some countries, if the legal aid beneficiary wins or keeps money in his case, he/she may be required to pay up to the full cost of the work done for him/her. ${ }^{63}$

There is a difference between countries on who is eligible for legal aid and on which criteria.

\section{Legal Aid Provision Criteria}

Generally speaking, if based on the defined criteria, a person is eligible to receive legal aid based on the scope of legal aid in a particular country, the lawyer, legal counsel, and procedural representative (if needed) will be nominated or the person can select the lawyer or procedural representative himself. Accordingly, fees and costs of the legal aid are fully or partially covered by the state.

In civil and administrative cases, before nominating the lawyer, legal counsel, or procedural representative or giving them permission to provide legal aid, an assessment of the person's eligibility is performed by applying eligibility criteria. All countries apply means and merit as well as other related criteria.

\section{Means Test-Assessment of the Financial Situation of the Applicant}

A financial means test consists of an assessment of the applicant's income and assets. Depending on an applicant's financial situation, some people pay nothing towards legal aid, others might have to pay something towards it, and some might not be financially eligible at all.

Some countries provide fully covered legal aid, ${ }^{64}$ whereas others have several levels of coverage ${ }^{65}$ or growing levels of coverage which depends on the particular financial situation of the beneficiary. ${ }^{66}$ In some countries, legal aid is never completely free and this payment is called a legal aid fee. ${ }^{67}$ Finally, it should be mentioned that there is one country, i.e., Poland, whose means test does not have any thresholds for assessments. The court grants coverage of court fees and costs of proceedings and appoints the lawyer based on discretional assessments of whether the applicant - individual shows that they are unable to bear the cost of proceedings without prejudicing their and their family's livelihood. Means criteria are not clear and this allows judges wide discretion on whether to provide or deny legal aid.

Regarding the issue of assessment of a person's income, it could be said that some countries use an easy understandable formula whereas others have formulas that are very complicated for applicants to understand. Most countries assess the applicant's income taking into account the household income, whereas only a few uses an assessment based on the personal income of the applicant. ${ }^{68}$ Some countries make an assessment based on the monthly incomes, ${ }^{69}$ whereas others are based on annual income of previous year ${ }^{70}$ or even two years before. ${ }^{71}$ Some countries take only the income into account ${ }^{72}$ whereas others make an assessment based on the disposable income, i.e., from income left after deducting incurred expenses ${ }^{73}$ or deducting a fixed deductible sum. ${ }^{74}$ For example, in Germany, the following are allowed as deductions from the gross income: a tax-free amount of EUR

${ }^{63}$ Germany, Scotland, Spain, Northern Ireland, England and Wales, France.

${ }^{64}$ Spain, Italy, Denmark.

${ }^{65}$ Lithuania and Belgium have two levels of coverage, France - three levels, Sweden-five levels.

${ }_{67}^{66}$ Netherlands, Germany, Finland, Hungary, Northern Ireland, England \& Wales, Scotland.

${ }^{67}$ Sweden, Netherland.

${ }_{68}^{6}$ Lithuania, Belgium, Hungary.

69 France, Belgium, Germany, Finland, Hungary, England and Wales.

${ }^{70}$ Spain, Lithuania, Italy, Sweden, Denmark, Scotland, Northern Ireland.

71 E.g. Netherland, Legal Aid Board, Legal Aid in the Netherlands a broad outline-Edition: September 2017, p. 17.

72 Spain, Lithuania, France, Belgium, Italy, Denmark, Hungary, England \& Wales, Scotland.

73 Germany, Sweden, Finland.

${ }^{74}$ For example, in Ireland EUR 11,500 is deducted from a person's disposable income. 
473 for the party; a tax-free amount of EUR 473 applicable for the spouse or registered partner; the tax-free amount for each dependent child with regard to the child's age: (a) EUR adults 377; (b) young people from the beginning of their 15th year up to the age of EUR 18, 359; (c) children from the beginning of their 7th year until the age of 14, EUR 333; and (d) children up to the age of six, EUR 272; an additional tax-free amount of 215 EUR is applicable for the party, which receives income from employment; the housing costs (rent, utilities, heating); any other amounts with respect to specific difficulties (such as physical disability). The remainder then is regarded as income for granting of legal assistance-with or without partial contribution.

In all countries, the threshold for income level is increased based on the number of cohabitants and dependants of the applicant. In some countries, the threshold levels are defined by setting a concrete figure, ${ }^{75}$ whereas in others, it is based on a formula which includes as a multiplier the Multi-Purpose Public Income Index $^{76}$ or Minimal monthly salary. ${ }^{77}$ In all countries, financial threshold criteria are revised periodically. The level of financial threshold differs greatly among the countries. In some countries, $2 \%-3 \%$ of the population ${ }^{78}$ are eligible for legal aid whereas in others even $80 \%$ of the population ${ }^{79}$ are covered by the legal aid scheme. In those countries where assessment is based on the disposable income, the legal aid beneficiary is required to pay a contribution in instalments or periodical fees. ${ }^{80}$ In those countries which make an assessment on gross income or income after tax deduction, a particular percentage of legal aid coverage is defined. ${ }^{81}$ Some countries require that the contribution, instalment, or periodical fee be paid directly to the lawyer, whereas others require it to be paid to the state treasury. In some countries, means test criteria are applied during the legal aid provision period whereas in others, for example, Germany, this continues for years after legal aid provision has finished. There are several countries which require payment of instalments for up to four years. ${ }^{82}$

The assessment of a person's assets differs greatly among countries as well. Some countries take into account the value of all capital, ${ }^{83}$ whereas others disregard the flat or house in which the applicant lives ${ }^{84}$ or disregard seized property ${ }^{85}$ or mortgaged property. ${ }^{86}$ Some countries calculate ${ }^{87}$ or define ${ }^{88}$ the value of capital normative and compare it with the value of capital actually owned. For example, in Lithuania, a person can get $100 \%$ covered legal aid if the value of all disposable capital does not exceed the value of the capital normative

\footnotetext{
${ }^{75}$ In France, the Level I income threshold is EUR 1,007 per month, II Level—up to EUR 1,190 per month and III Level—up to EUR 1,510; In Belgium, the Level I threshold is EUR 978 per month and II Level is EUR 1,255 per month; In Italy, the Level I threshold of income is EUR 11,528.41 per month; In Sweden, the Level I income threshold is EUR 4,864.61 (50,000 SEK) per year, II Level—EUR 9,729.23 (100,000 SEK), III Level—EUR 11,675.08 (120,000 SEK), IV Level—EUR 14,593.85 (150,000 SEK), V Level EUR 19,458.47 (200,000 SEK), VI Level-EUR 25,296 (260,000 SEK) per year; In Finland, free legal aid available for those whose income is up to EUR 600-1,300 per month; In Hungary, EUR 190-250 per month, in England and Wales up to GBP 2,657 in Ireland up to EUR 18,000 per year.

${ }^{76}$ In Spain $2 \times$ the Multi-Purpose Public Income Index (IPREM) for single person (EUR 12,780.26; $2.5 \times$ IPREM for a family of 2-3 members (EUR 15,975.33); $3 \times$ IPREM for a family of 4 and more members (EUR 19,170.39).

${ }_{77}$ In Lithuania Level I-10 x Minimal Monthly Salary (MMI) (EUR 5,550); II Level-15 MMI (EUR 8,325) (05/04/2019).

${ }^{78}$ Hungary, Italy.

79 Sweden.

${ }^{80}$ Germany, Scotland, Sweden.

81 E.g. Lithuania.

82 Germany, Scotland.

${ }^{83}$ Lithuania.

${ }^{84}$ France, Spain.

${ }^{85}$ Lithuania.

${ }^{86}$ England and Wales, The mortgage is disregarded of up to a maximum of GBP 100,000.

87 Lithuania.

${ }^{88}$ For example, in Ireland to get civil legal aid, an applicant will need not only to have an annual disposable income of less than EUR 18,000, but also to have disposable assets of less than EUR 100,000.
} 
and $50 \%$ coverage - if the value does not exceed $1.5 \times$ normative. The value of the capital normative consists of the value of immovable property normative and the value of movable property and assets normative. The value of immovable property normative consists of the value of accommodation normative ${ }^{89}$ and value of land normative $^{90}$. In addition to the value of the immovable property normative, the value of movable property and assets normative is taken into account. The total value of the movable property and assets normative (financial assets and other) is calculated: $45 \mathrm{SGI}^{91}$ for the applicant +30 SGI for every adult family member +15 SGI for every child up to the age of 18 .

\section{Groups of Vulnerable People}

All EU countries studied have lists of vulnerable people to whom legal aid is provided regardless of their income and assets. However, the number of groups of vulnerable people varies greatly among the countries. Most countries agree that as a minimum four groups of people should be included in the list of vulnerable people:

- persons receiving social allowances, receiving family benefits, welfare benefits, minimum income support, solidarity allowance for elderly people or old person' guaranteed income (Lithuania, France, Belgium, Hungary, Scotland, and Spain);

- minor children, independently applying for the defence of his/her rights or interests (Lithuania, France, Belgium, Italy, England \& Wales, and Ireland);

- other persons in cases provided for in the international treaties (including asylum seekers, refugees, or temporarily protected person) (Lithuania, France, Belgium, Italy, Hungary, Ireland, and England \& Wales);

- persons who is requested to recognise as legally incapable, review decision on incapability, defending their rights in other proceedings, in issues of their forced hospitalisation (Lithuania, France, Italy, and England \& Wales).

In addition to that 2-3 countries added to the list, an additional three groups of people:

- persons maintained in stationary care or medical care institutions (Lithuania, Italy, Hungary);

- persons who have a severe disability or incapacity for work or whose level of considerable special needs has been established (Lithuania and Hungary);

- children at risk of being taken into care (England \& Wales, and Ireland).

Finally, the list below shows groups of people which have been recognised as vulnerable people in any one country:

- beneficiary of the minimum legal wage allowances (France);

- those receiving income substitution allowances for disabled people not receiving the integration allowance (Belgium);

- a party who cares for a child in their family who has been declared eligible to receive regular child welfare subsidies (Hungary);

- appealing a decision made by the social security tribunal about someone's benefits to the Upper Tribunal,

\footnotetext{
${ }^{89}$ (60 square metres for the applicant +15 square metres for every dependent of the applicant) $\mathrm{x}$ the value of 1 square metre of the property.

${ }^{90}$ Depends in which territory and what type of land the applicant has: (60 square metres (city) or 250 square metres (villages or small towns) or 3.5 hectares agricultural land, lake, forest (for the applicant)) $\mathrm{x}$ the value of 1 square metre/hectare of the land; If the applicant does not have land, the value of 60 square meter in place of residence is taken into account.

91 SGI - state-guaranteed monthly income defined by Resolution of the Government of the Republic of Lithuania. At 05/04/2019 it is EUR 122.
} 


\section{Court of Appeal or Supreme Court (England \& Wales);}

- needing advice on children or divorce proving an abusive relationship (England \& Wales);

- debtors in execution proceedings, when a recovery is levied against the last housing (Lithuania);

- parents of minor children, in the issue of their eviction (Lithuania);

- persons in matters concerning registration of birth (Lithuania);

- tenants of social housing who in the Flanders and Brussels Capital Regions pay rent at half the basic rate or who in the Wallonia Region pay a minimum rent (Belgium);

- a homeless person spending the night at temporary lodgings (Hungary);

- those who, due to an accident, can prove permanent consequences that completely prevent them from performing the duties of their regular job or profession and who require the help of other people to perform essential daily activities, when the object of the litigation is a claim for compensation for personal injury and moral damages (Spain);

- foreign nationals presenting an application for regularisation of residence status or appealing against an expulsion order (Belgium);

- any party who is requesting legal aid in connection with obtaining a visa, obtaining authority to reside or permanent resident status, or in a naturalisation case, whose descendant is or has previously been a Hungarian citizen and the party is engaged in a repatriation procedure (Hungary);

- discriminated person (England \& Wales).

\section{Merit Test}

Summarising the practice of the EU countries studied it could be said that the Merit Test consists of three tests. These are:

- the prospect of success test;

- the prudent self-funding litigant test;

- the appropriateness of spending limited public legal assistance funds test.

The prospect of success test. In six countries out of 14, the prospect of the success test is very favourable to the legal aid beneficiary. Legal aid will not be provided if claims are manifestly unfounded ${ }^{92}$ or obviously inadmissible and devoid of substance, ${ }^{93}$ apparently is without any merit ${ }^{94}$ and/or representation does not have any chance of success. ${ }^{95}$

Relying on the precedence of Lithuanian courts, this means that legal aid could not be provided only in cases where it can be unanimously concluded there is no any chance for success in defending the claim in court. For example, the final decision has already been taken by courts.

On contrary, other countries use a less favourable test. For example, in Denmark, legal aid is provided in cases where there is a reasonable expectation that the applicant can win the case ${ }^{96}$, i.e., it must have a certain importance and there is a fair chance that the court will rule in his favour. In Germany, ${ }^{97}$ the action the applicant

\footnotetext{
92 E.g. Belgium, The Judicial Code of 1967, Art. 667; Lithuania, Law VIII-1591 on State-Guaranteed Legal Aid, Art. 11(7)(1); Italia, Decree of the President of the Republic May 30, 2002, No. 115 Consolidated text of the legislative and regulatory provisions on the cost of justice. (Text A), Italy, published Official Journal No. 139 of 15 June 2002, Art. 74(L)(2).

93 E.g. France, Law No. 91-647 on Legal Aid, Art. 7.

94 Netherland, Legal Aid Act of 1993, Art. 12(2)(a).

95 E.g. Lithuania, Law VIII-1591 on State-Guaranteed Legal Aid, Art. 11(7)(2).

96 Denmark, Danish Administration of Justice Act, §327(4).

97 Germany, Code of Civil Procedure, $\$ 114$.
} 
intends to bring or an action that has been brought against him has to have sufficient prospects of success. In Scotland, legal aid may not be granted if it looks unlikely that applicant will succeed in the proceeding. ${ }^{98}$ Similar to Scotland in Northern Ireland, a person may be refused legal aid if, in the particular circumstances of the case, it appears unreasonable that he should receive it. ${ }^{99}$

The prudent self-funding litigant test. To satisfy this test the matter must, if successful, produce a real benefit to the aided person, so that the ordinarily wise and sensible self-funding litigant would risk his or her own funds for such a matter ${ }^{100}$.

Situations in which this test will not be met include where ${ }^{101}$ :

a. The cost of the matter outweighs the benefit;

b. The applicant wants to defend a claim, but has nothing of substance to lose;

c. The applicant wants to sue for money, but the other party will not be able to pay.

The cost of the matter outweighs the benefit. Some countries directly define the value of the claim in which legal aid is provided. For example, in Spain, legal aid is available in all cases with a value of over EUR 2,000 and in case of smaller value, legal aid is provided where the other party in the proceedings has a legal representative or where a judge explicitly requires that a legal representative be appointed to ensure equality for both sides. Likewise, in Sweden, a person will not receive legal aid if the value of the matter/dispute is less than SEK 22,000 (EUR 2,140.43). There must be a special reason to grant legal aid in lower value cases.

Other countries compare the value of the case with the cost of legal aid provision. For example, in Lithuania, it is defined that legal aid will not be provided if the costs of legal aid would exceed the amount of the applicant's pecuniary claims (pecuniary interests). Similar in Finland, it is set that legal aid will not be provided if it would be clearly pointless in proportion to the benefit that would ensue to the applicant. Finally, in Scotland, legal aid may be not granted if a case will cost much more than it is worth.

The applicant wants to defend a claim, but has nothing of substance to lose. An example of the application of this criterion can be found in the law of Germany, Lithuania, Scotland, Finland, England and Wales as well as Hungary.

In Germany, ${ }^{102}$ legal aid is provided in cases in which the action the applicant intends to bring or an action has been brought against him/her does not seem frivolous. "Does not seem frivolous" means the party would not start the process if he/she had to bear the costs itself (lack of willingness). ${ }^{103}$

In Lithuania, legal aid is not provided to an applicant who is seeking to protect somebody else's rights; the claim in question has been passed to the applicant with the purpose of receiving free legal aid; the submitted claim seeks to protect honour and dignity, however, there was no material damage (property damage) suffered. ${ }^{104}$

In Scotland, legal aid is provided in situations where the probabilis causa litigandi. ${ }^{105}$ There has to be a legal basis for the case (called "probable cause") whereas in Finland, legal aid is not provided when the matter is

\footnotetext{
98 Legal Aid (Scotland) Act 1986, Art. 14(1)(a).

99 Northern Ireland, Legal Aid, Advice and Assistance (Northern Ireland) Order 1981 Art. 10(5)(a).

100 Legal Services Commission of South Australia, Legal help for all South Australians, https://lsc.sa.gov.au/cb_pages/merit_test.php.

101 id.

102 Germany, Code of Civil Procedure, $\S 114(1)$.

103 Germany, Code of Civil Procedure, $\$ 114(2)$

104 Lithuania, Law VIII-1591 on State-Guaranteed Legal Aid, Art. 11(7)(3)(6)(7).

105 Legal Aid (Scotland) Act 1986, Art. 14(1)(a). In Latin. A probable cause of action. A person applying for legal aid has to show a reasonable basis for the proposed legal action.
} 
of little importance to the applicant and the matter is based on an assigned right and there is reason to believe that the purpose of the assignment was the obtainment of legal aid. ${ }^{106}$

In England \& Wales, the claim must satisfy the "sufficient benefit" test where legal aid may only be provided where there is sufficient benefit to the client, having regard to the circumstances of the matter, including the personal circumstances of the client, to justify work being carried out. ${ }^{107}$ In most cases, it will be necessary to show that the prospects for success are at least $50 \%$ but, in some circumstances, "marginal" and "borderline" cases will be eligible.

The applicant wants to sue for money, but the other party will not be able to pay. An example of the application of this criterion can be found in the regulations of Scotland only. A legal aid provider in this country may not see it reasonable to grant legal aid if the person somebody is trying to sue has no money. ${ }^{108}$

Appropriateness of spending limited public funds. To satisfy this test, the matter must be one on which it is appropriate to spend limited public funds. Accordingly, legal aid will only be granted for a deserving and proper purpose $^{109}$.

Situations in which this test will not be met include where:

- The claim arises directly in relation to the applicant's commercial activity or activities of self-employed (Lithuania and Denmark);

- There is an abuse of the right to free legal aid or an abuse of process (Lithuania and Finland);

- The applicant can exercise or defend his rights or interests does not addressing the court (Lithuania, Scotland, Germany, Scotland, and Sweden);

- Not all the possibilities have been exempted for solving the dispute peacefully (Germany);

- The person needs to apply for debt relief (Denmark and Italy);

- The person has insurance ${ }^{110}$ or does not have insurance but, based on their financial situation, they ought to have had insurance; they will not receive legal aid (Sweden);

- The party's litigation costs will not be higher than four monthly rates and will not exceed the instalments amounts to be contributed from the party's assets. ${ }^{111}$ In Germany, it is a requirement that the litigant has to use their own assets to cover the litigation costs as much as reasonably possible;

- An average person (not a wealthy person) would not be willing to go to court if he/she was paying for it with his own money (Ireland);

- A solicitor or a barrister acting reasonably would not recommend a person to go to court, knowing he/she were paying for it himself /herself and based on the facts of his/her case (Ireland);

- It is not reasonable that the state pays the costs in the dispute (Sweden).

In some countries, i.e., in Hungary, the merit test is not specified. The general notion defined by the Court of Human Rights is applied. In this country, legal aid will be provided if the interest of justice so requires, if legal representation is mandatory in the procedure (before appeals courts, the Supreme Court and in extraordinary

\footnotetext{
${ }_{106}$ Finland, Legal Aid Act, §7(1)(4).

${ }_{107}$ England \& Wales, Legal Aid, Sentencing and Punishment of Offenders Act 2012, Art. 11(3)(a).

108 Scottish Legal Aid Board, A Guide to Civil Legal Aid (2009), https://www.slab.org.uk/common/documents/getting_legal_help/pdf/guide_civil_2009.pdf, §3.2.

109 Legal Services Commission of South Australia, Legal help for all South Australians, https://lsc.sa.gov.au/cb_pages/merit_test.php.

${ }_{110}$ Sweden, Denmark, Scotland, Lithuania, Germany.

111 Germany, Code of Civil Procedure, §115(4).
} 
judicial remedies) and due to the lack of legal knowledge or the complexity of the case, the person may be unable to effectively represent his/her interests or exercise his/her rights in the procedure. ${ }^{12}$

Finally, it should be pointed out that in some countries in exceptional situations fulfilment of merit test criteria can outweigh non-fulfilment of means test criteria. For example, in France, in exceptional circumstances the applicant may still be eligible to receive legal aid even if the financial resources of the applicant exceed the limits. This can happen in cases when their action is particularly worthy of interest given its subject matter and the likely costs.

\section{Conclusion}

Situation analysis shows that the variation of the conditions on the legal aid provision is so big among the countries that the same person eligible for legal aid in one country is not eligible in another. EU countries should seriously consider whether it would be sound to seek unification of the regulation.

${ }^{112}$ Hungary, 2016 CXXX. Code of Civil Procedure, Wolters Kluwer Hungary Kft. (2016), §73(1), 98. 